\title{
"Green" Composites for North-Arctic Region Development
}

\author{
Valery Lesovik ${ }^{1}$, Arcady Ayzenshtadt ${ }^{2}$, Maria Frolova ${ }^{2}$, Ruslan Lesovik ${ }^{1, *}$ and Valeriya Strokova ${ }^{1}$ \\ ${ }^{1}$ Belgorod State Technological University, Russia, 308012, Belgorod, Kostykova str., 46 \\ ${ }^{2}$ Northern (Arctic) Federal University, Russia, 163002, Arkhangelsk, Severnaya Dvina Emb., 17
}

\begin{abstract}
This paper discusses some of the major environmental problems of North-Arctic region. It has been proposed to use provisions of Architectural geonics and "green" composite compounds with nanodisperse organic mineral additive to improve the ecological situation in the region and enhance the effectiveness of the "Man-Material-Habitat" system.
\end{abstract}

Keywords: Architectural geonics, ecology, geonics, green composites, high-strength fine-grained concrete, saponite, the Arctic, technogenic raw materials.

\section{INTRODUCTION}

The Arctic is one of the most fragile ecosystems on the planet. The Arctic region consists of eight countries: Canada, Denmark (including Greenland and the Faeroe Islands), Finland, Iceland, Norway, Russian Federation, Sweden and the USA. Currently, environmental problems in the Arctic are likely to grow from regional to global ones because of its natural geographic features, that threaten to destabilize the climate, geochemical, cryolite and ecological processes within large parts of the northern hemisphere.

Many severe environmental problems in the Arctic are caused by poor environmental management. These problems include: economic development that does not match the ecological capacity of natural environment at the substantial absence of adequate measures for its rehabilitation; the limited range of natural resources use within the area; and the conflict between different types of nature use (Jushkin 2008).

Therefore, this region is of strategic interest today in terms of rich mineral resource volume and huge unexplored territories. For example, the Arkhangelsk region has considerable reserves of mineral resources and hydrocarbons, forests, extractive industries and wood-chemical facilities (Table 1), and atomic shipbuilding; also one of the main country spaceports "Plesetsk" is actively operated here.

The economic development of the Arctic entails the increase of anthropogenic pressure on the environment against its low ability to restore itself, and also has an adverse effect on public health.

In the Arctic regions, human diseases have their own particular distribution that is more associated with environmental factors in the region and the state of organism

*Address correspondence to this author at the Belgorod State Technological University named after V.G. Shoukhov, Russia, 308012, Belgorod, Kostykova str., 46; Tel: +7 (4722) 54-20-87; Fax: +7 (4722) 55-71-39;

E-mail: ruslan_lesovik@mail.ru adaptation. The main factors influencing the decrease of the human immune and endocrine system reserves in the North are the length of northern period; environmental causes (heat, light, minerals deficiency, an intense ion-magnetic regime, sharp fluctuations of climatic parameters); photoperiodic (the longest night and the shortest day in winter, the shortest night and the longest day in summer); seasonality, and age (Tikhonov 2010).

The negative impact on human health and psychoemotional state has a number of social factors, such as high rate of unemployment, the deterioration of demographic situation, rugged and monotonous landscape and the uniformity of modern architectural forms that do not meet the specifics of the north (e.g. the panels of 9-10 storey buildings, blown by northern winds and located excluding the polar day and polar night phenomena).

Historically, architectural forms of buildings and structures in northern regions were developed considering the protection of residential, business premises, and offices from low temperatures, atmospheric moisture, deep snow cover, and sharp northern winds. A traditional northern house is an object of low-rise building highly raised above the ground level with a compact volume. An expressive appearance of a building was therefore attained by a successful house volume and outbuildings ratio, by the proportional mutual spatial arrangement of openings and walls between these openings, a combination of masonry inserts with wood paneling, and the colors corresponding to the northern landscape (Fig. 1) (Barashkov 2011).

\section{DISCUSSION}

Nowadays, we can deduce the relationship violations concerning northern cities structure within the balanced system "man-material-environment". Therefore, a new scientific trend "Architectural Geonics" has emerged as being the most important one for the territories of the North and Arctic regions. The main provisions of this trend are 


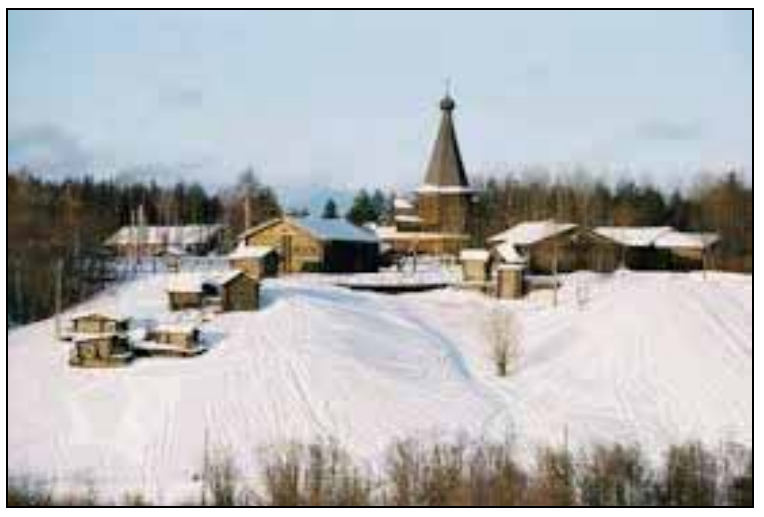

a)

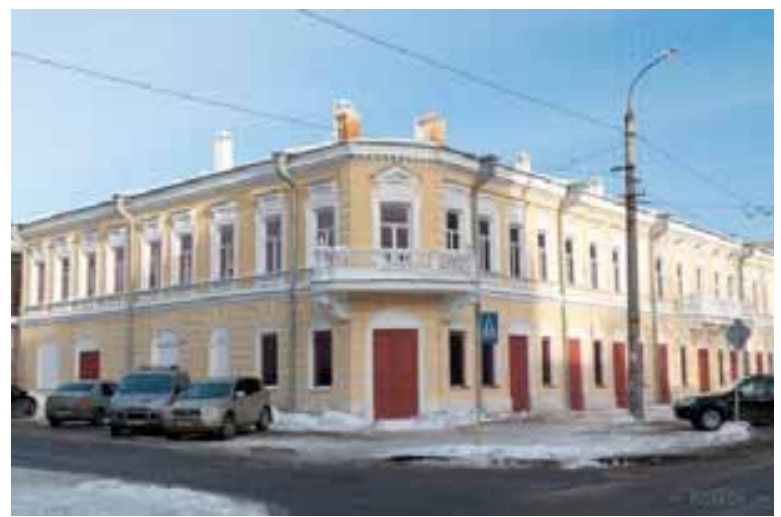

c)

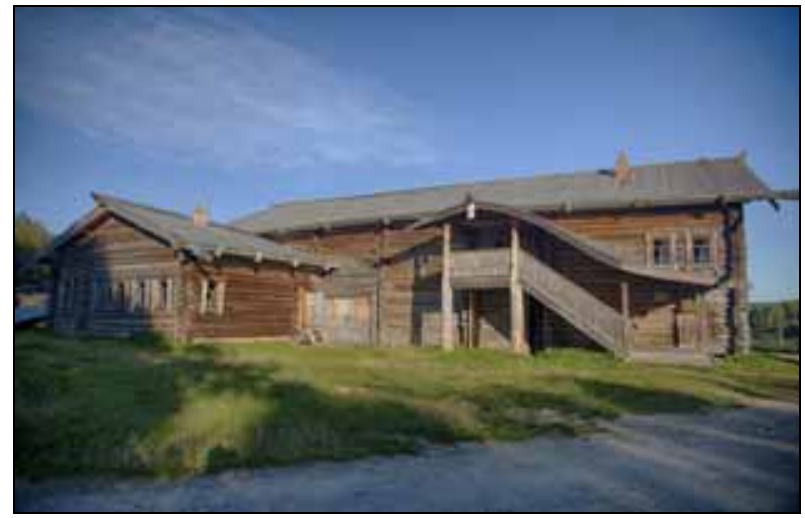

b)

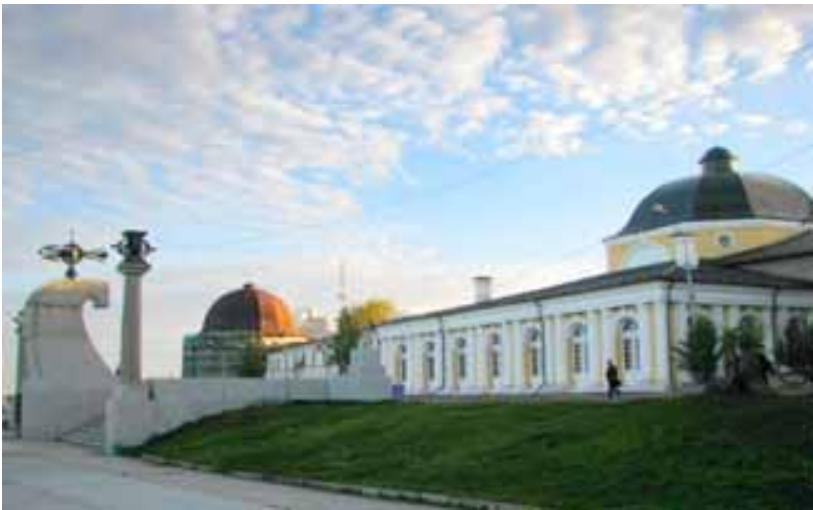

d)

Fig. (1). Architectural forms of buildings and structures of the Northern regions: a) and b) Malye Korely - the museum of wooden architecture and folk art of the northern regions of Russia; c) E.K. Plotnikova manor house, Arkhangelsk, 1784; d) Guest house, Arkhangelsk, 1668-1684.

primarily aimed at the improvement in human existence by designing structures which should organically fit into the environment in accordance with geomorphology, climate, cultural traditions and the use of "green" composite materials (composite binders, industrial wastes, energy-saving materials, etc.) for construction. The architectural geonics influence on psychological climate development, positive emotion, creative mood, mental activity and human longevity generation may be regarded as one the basic aspects for the infrastructural development of the territory (Lesovik 2013 a,b, 2012, 1994).

The course of arctic national development strategy of Russia until 2020, which provides, among other things, the construction of new ports and the renovation of old ports, the installation of a railway network and power transmission lines, the development of the social structure of Arctic towns and cities. Raising the level of environmental and ecological safety in oil and gas production in the Arctic regions, including the effective socio-economic development on the shelf of the Arctic seas of Russian northern territories.

One way to achieve this goal, allowing the increase in the efficiency of "Man-Material-Habitat" system interaction, is the range of expansion and architectural splendor. Besides, the transition to an eco-friendly construction is the primary issue. To reduce energy consumption of such buildings, it is reasonable to use the latest achievements in the field of building material science, the creation of "green" composite materials, containing $40 \%$ of natural and environmentally friendly anthropogenic raw materials.

The aim of this work is the assessment of the environmental situation improvement possibility of the North-Arctic region (for example in Arkhangelsk region) by the creation and use of "green" building composites.

The North European part of Russian Federation is characterized by extreme climatic conditions, with some being unfavorable for construction by engineering and geological conditions; the focal nature of industrial and economic territory development activities related to its remoteness and inaccessibility. However, the region is rich in deposits of raw materials for construction material production.

The region has the largest primary diamond deposit in the European part of the country named after M.V. Lomonosov. The comprehensive study of kimberlite ore mineral and sludge waste composition of the deposit showed that the most part of kimberlite mine refuse is presented by the colloidal saponite-water system (over 65\%) and to a lesser extent by liquid clays (Ayzenshtadt 2012). Saponite is a clay mineral (a layered silicate from the montmorillonite group). It is nontoxic, has a chemical resistance, making it useful in many areas of the construction industry. At the same time, 


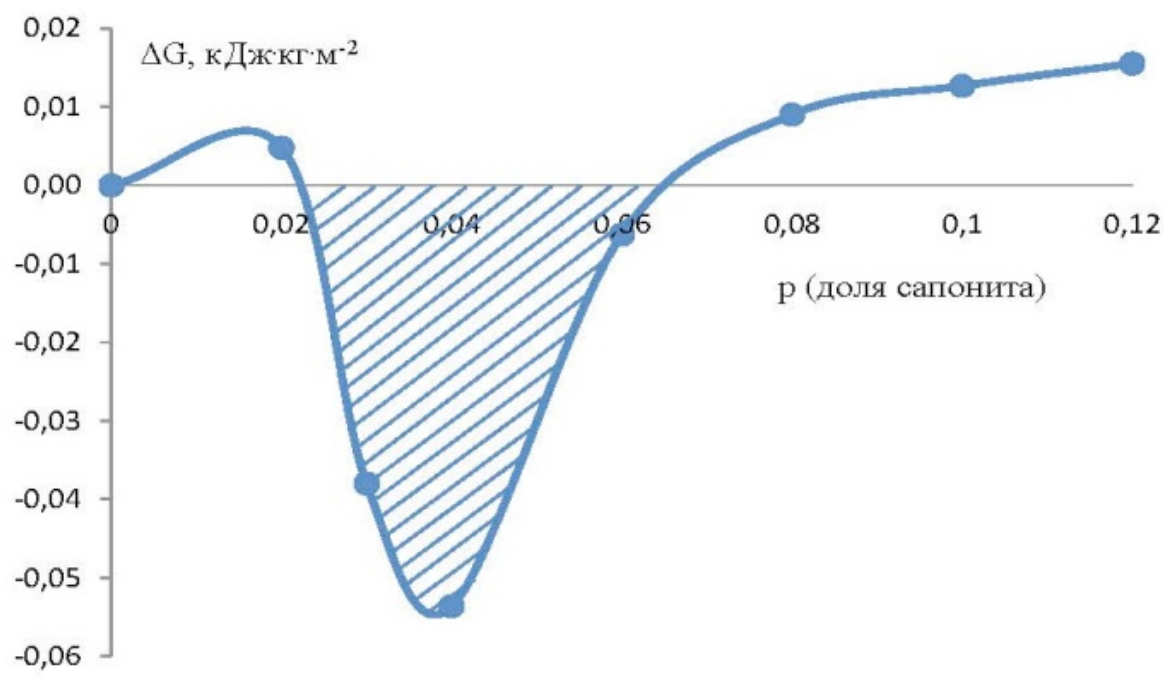

Fig. (2). The functional dependence of $\Delta \mathrm{G}_{\mathrm{S}}=f(\mathrm{p})$, where $\Delta \mathrm{G}_{\mathrm{S}}$ is the change of the system isobaric-isothermal potential; $\mathrm{p}$ is the saponite share.

Table 1. Mineral resources of the Arkhangelsk region for building material production (http://www.dvinaland.ru/social/protection/, Nevzorov 2007).

\begin{tabular}{|c|c|}
\hline Raw Material Type & State and Amount of Deposits \\
\hline \hline For cement production & 3 deposits \\
\hline For silicate products manufacture & 11 of 12 balanced deposits are in an unallocated fund \\
\hline For concrete manufacture & 1 deposit is abandoned \\
\hline Building stones & 3 of 10 balanced deposits are in an unallocated fund \\
\hline Plaster stone & 1 of 4 balanced deposits are in an unallocated fund \\
\hline Clays for brick production & 39 of 41 balanced deposits are in an unallocated fund \\
\hline Clays for ceramsite production & 3 deposits are in an unallocated fund \\
\hline Sandy gravel compounds and building sands & \\
\hline
\end{tabular}

saponite-bearing kimberlite ore wastes are characterized by extremely low contents of sulfur, phosphorus, zirconium, strontium, arsenic, and radioactive elements, so they can be considered as a valuable raw material for green composites production (Frolova 2011; Tutygin 2012).

The prospect of local raw material use to improve the quality and competitiveness of construction composite materials is presented by the work of organic mineral nanodisperse modifier design (ONM) on the basis of finegrained sand of "Krasnoflotskiy-Zapad" deposit and saponite-bearing kimberlite ore refuses of diamond industry. The usefulness of the modifier use as an additive for finegrained concrete is demonstrated. Unlike conventional concrete with coarse filling, fine-grained concrete has high flexural strength, good water and frost resistance.

We have developed a thermodynamic model that takes into account the change of isobaric-isothermal potential and the surface tension of a highly dispersed system to optimize the component composition of highly resistant fine-grained concrete (Fig. 2). We determined the relation of components exhibiting an increased energy activity (isobaric-isothermal potential of the system is less than zero), which made it possible to optimize the structure of organic mineral nanodisperse modifier for fine-grained concretes, the additive of which may considerably increase the composite strength (Tutygin 2013).

During further studies, high-strength concrete compositions were developed from the samples of concrete with improved physical and mechanical properties and a minimum volume of a binder component were obtained and tested (Table 2).

\section{CONCLUSION}

Concrete with ONM addition is characterized by low levels of water absorption and abrasion resistance, high resistance to frost, and increased compressive strength, which make it possible to apply in various areas of construction industry (Fig. 3). Besides, it should be noted that the decrease in cement component consumption is fully 
Table 2. Physical and mechanical properties of fine-grained concrete on ONM basis

\begin{tabular}{|c|c|c|c|c|c|c|c|c|c|}
\hline \multirow{2}{*}{$\begin{array}{l}\text { Compositio } \\
\text { n № }\end{array}$} & \multicolumn{4}{|c|}{ Concrete Compound Content, $\mathrm{kg} / \mathrm{m}^{3}$} & \multirow{2}{*}{ W/C } & \multirow{2}{*}{$\begin{array}{l}\text { Compound } \\
\text { Placeability }\end{array}$} & \multirow{2}{*}{$\begin{array}{l}\text { Crushing Stress, } \\
\text { R }_{\text {sr }} \text { MPa, } 28 \text { days }\end{array}$} & \multirow{2}{*}{$\begin{array}{c}\text { Prism Strength, } R_{r} \\
\text { MPa, } 28 \text { days }\end{array}$} & \multirow{2}{*}{$\begin{array}{c}\text { Concrete Class, } \\
\text { B }\end{array}$} \\
\hline & Binder & Sand & Water & ONM & & & & & \\
\hline 1 & 570 & 1460 & 200 & - & 0,35 & Ж5 & 45,3 & 35,3 & 35 \\
\hline 2 & 570 & 1460 & 153 & 43 & 0,27 & Ж5 & 79,2 & 60,8 & 60 \\
\hline 3 & 370 & 1650 & 100 & 28 & 0,27 & ж5 & 47,2 & 36,2 & 35 \\
\hline 4 & 403 & 1625 & 141 & 30 & 0,35 & Ж3 & 54,7 & 42,1 & 40 \\
\hline 5 & 415 & 1610 & 166 & 31 & 0,4 & П1 & 53,4 & 40,7 & 40 \\
\hline 6 & 430 & 1550 & 242 & 32 & 0,55 & П2 & 49,0 & 38,8 & 35 \\
\hline 7 & 488 & 1490 & 161 & 37 & 0,33 & Ж4 & 67,2 & 53,4 & 50 \\
\hline 8 & 560 & 1448 & 224 & 42 & 0,4 & П1 & 72,4 & 56,7 & 55 \\
\hline 9 & 541 & 1407 & 173 & 41 & 0,32 & Ж4 & 74,0 & 57,4 & 55 \\
\hline
\end{tabular}

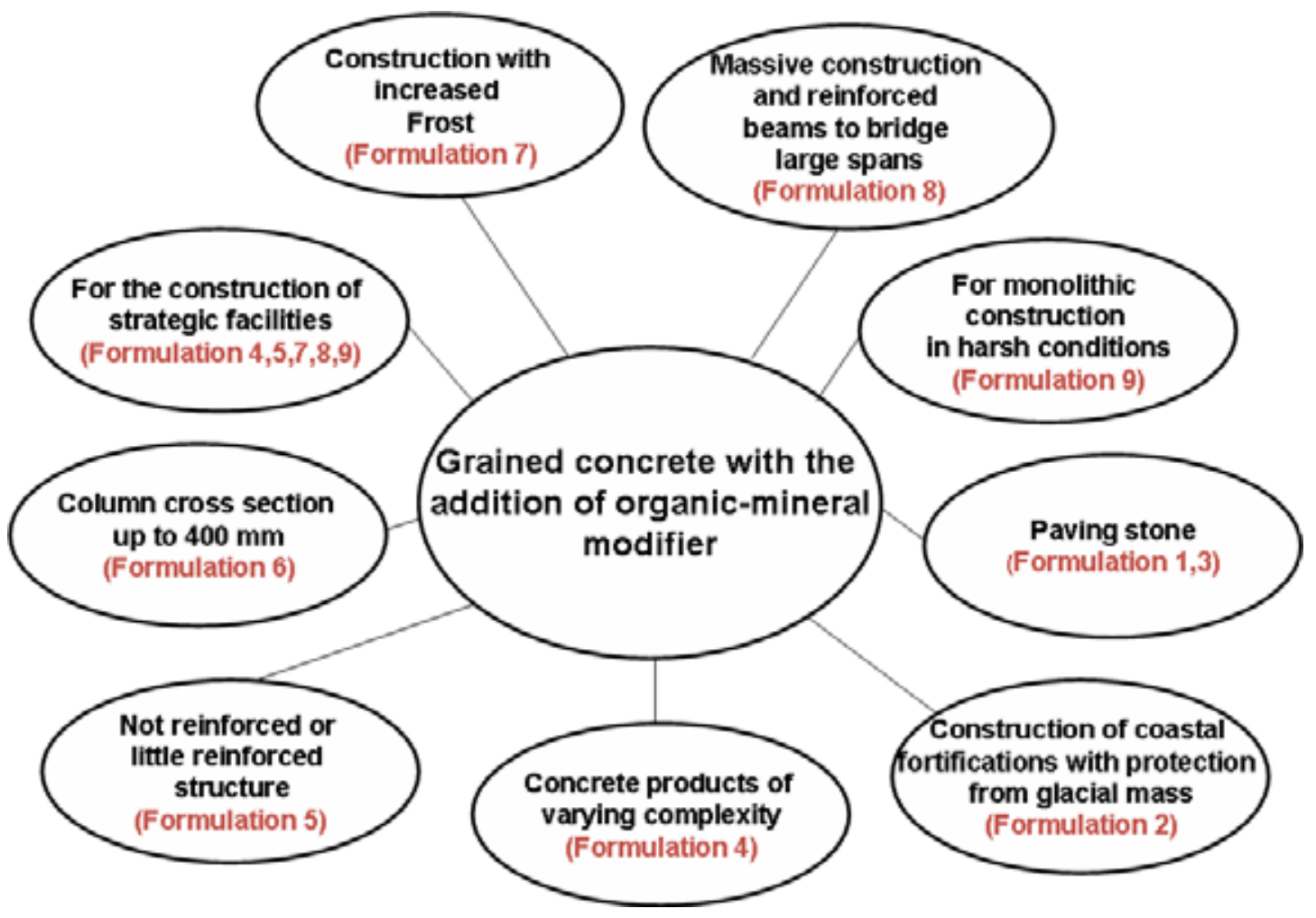

Fig. (3). Application fields for proposed fine-grained concrete compositions.

compliant to the "green" composites. The high-temperature processing of raw materials for each finished product (concrete) is reduced, which is the basis for mineral binders production, finally leading to $\mathrm{CO}_{2}$ emission reduction.

The use of anthropogenic raw materials for diamond industry as the raw material for concrete production ("green composites") will make it possible to reduce the environmental burden of the region, make it eco-friendly, as well as to increase the profitability of diamond deposit production.

\section{SUMMARY}

Based on the foregoing, it is possible to formulate the principles of obtaining and using green building composite materials intended for Northern Arctic areas:

For green composite material production it is appropriate to use local, readily available energy-efficient materials (with a large energy potential), as well as a safe man-made materials, the use of which will reduce the environmental burden on the region ecology. 
The creation and practical application of green composites in ecological construction make it sometime necessary to take into account the basic provisions of geonics and architectural and geonics and it is advisable to use a thermodynamic approach for the calculation of energy system basic parameters to optimize the composition of composites.

Thus, the use of composite materials in green modern eco-friendly construction will expand the diversity of existing architectural forms to develop entirely new architectural solutions, the shape and coloring of which will emphasize the identity and culture of the Northern Arctic region, and thus improve the health and psycho-emotional state of people living in the North.

\section{CONFLICT OF INTEREST}

The authors confirm that this article content has no conflicts of interest.

\section{ACKNOWLEDGMENTS}

This work was financially supported by the federal target program "Scientific and scientific-pedagogical members of innovative Russia" in 2009-2013 and "Research and development of priority trends for scientific-technological facility of Russia in 2007-2013".

The authors express their deep appreciation and gratitude for Tutygin A.S., the head of the Laboratory, a senior lecturer of composite materials and construction ecology department at the Institute of Construction and Architecture SAFU named after M.V. Lomonosov for the consultation and active participation during result discussions.

\section{REFERENCES}

Ayzenshtadt, AM, Machova, TA \& Frolova, MA (2012) Design of nano-and microstructure of composite materials of construction. Industrial and Civil Construction, 10, 26-30.

Barashkov, YA (2011) The history of architecture. Russia in the context of the world of architecture. Arkhangelsk, 1, 440.

Frolova, MA, Tutygin, AS \& Ayzenshtadt, AM (2011) Application of thermodynamic approach to the assessment of the energy state of the surface of the dispersed materials. Nanotechnology in Construction, 6, 13-25.

Jushkin, NP (2008) Arctic science, history and politics. North: Arctic vector of socio-ecological research. Syktyvkar, 17-47.

Lesovik, VS (1994) Gridchin, A.M. Zum Problem der For- chung des System "Mensch-Stoff-Umwelt," In: Proceedings of 2. Ibaus, Internationale Baustofftagung, Weimar, 8 .

Lesovik, VS (2012) Geonics, subject and objectives. Belgorod, 100.

Lesovik, VS (2013) Architectural geonik. Housing Construction, 1, 9-12.

Lesovik, VS (2013) Geonik as an objective reality. Belgorod, 34.

Nevzorov, AL \& Korshunov, AA (2007) Investigation of the properties of tailing deposits as a source of anthropogenic impact on the environment. Proceedings of the universities. Forest Journal, 4, 140-4.

The official website of the Arkhangelsk region. Date Views: 11.12.2013, http://www.dvinaland.ru/social/protection/

Tikhonov, DG (2010) Arctic medicine. Yakutsk Univ YaSC SB RAS, 317.

Tutygin, AS, Frolova, MA, Aksenov, SE, Ayzenshtadt, AM, \& Lesovik, VS (2011) Natural raw materials for construction purposes in the North Arctic region. Mineral resources base of the Arkhangelsk region / ed. V.S. Lesovik. Arkhangelsk, 148.

Tutygin, A, Frolova, M, Aisenshtadt, A, \& Veshyakova, L. Determination of free surface energy of nano-dispersed materials. In: Proceedings of 18. Internationale Baustofftagung (18. ibausil), Beton und Betondauerhaftigkeit Durability of Concrete, 2.24.

Tutygin, AS, Ayzenshtadt AM, Lesovik, VS, Frolova, MA, \& Bobrova, MP (2013) Design and construction of composites based on thermodynamic compatibility of highly dispersed systems of rocks. Building Materials, 3, 74-6.

Received: May 04, 2014

Revised: June 04, 2014

Accepted: June 04, 2014

(C) Lesovik et al.; Licensee Bentham Open.

This is an open access article licensed under the terms of the Creative Commons Attribution Non-Commercial License (http://creativecommons.org/ licenses/by-nc/3.0/), which permits unrestricted, non-commercial use, distribution and reproduction in any medium, provided the work is properly cited. 